\section{Is science still credible currency for decision-makers?}

\author{
J Morag Mackay 지, ${ }^{1}$ Les Fisher [1] ${ }^{2}$
}

We all know a colleague, or maybe we have experienced it ourselves. We have clear scientific evidence to support a particular action but when we present this evidence to decision-makers, they ignore it. Inglorious examples can be found in recent debates around climate change and the best way to manage the COVID-19 pandemic. Is science become irrelevant in public health? How do we begin to address the apparent disconnect between science and decision? Achieving large scale, population health impact is totally dependent on engaging and persuading decisionmakers to invest in effective solutions, but how can you persuade these key stakeholders when science is no longer credible currency.

There is a clear answer to this question. We need strong scientific leadership in injury and violence prevention (IVP). And we need our scientific leaders to realise the strength of their science comes from being totally engaged with the public whose health is the subject of our effort.

Scientific leaders who collaborate, building strong multidisciplinary teams including thinking outside of the box in terms of relevant expertise and engaging broader perspectives on the issue under study, tend to ask applied questions and find innovative approaches to longstanding problems that take the broader view laid out in the socioecological model. ${ }^{1}$ They also empower their research teams, help build future scientific leaders and create a research culture that supports inclusion and acknowledgement of the end users and/or those impacted by injury as important partners in finding effective and acceptable solutions.

\footnotetext{
${ }^{1}$ Safe Kids Worldwide, Washington, DC, USA ${ }^{2}$ Injury Prevention Consult (Archivist, APHA, Injury Control and EMS Section), Delmar, New York, USA
}

Correspondence to J Morag MacKay, Safe Kids Worldwide, Washington, DC 20037, USA; mmackay@ safekids.org
And the rest is engagement... that is, the importance of grounding one's science in the world of decision-makers, implementers and the target audience of injury prevention interventions. Such engagement results in research questions are applied and relevant to real world settings and inputs, and solutions cocreated and framed in ways that will increase uptake and implementation. While there are a few strong examples of this approach in the injury field, we can do more to match advancements in other areas of health research, particularly clinical areas that have invested more heavily in knowledge translation science.

The injury field can learn lessons from its own past. There are historic examples within the injury field where evidence has been successfully used to make the case for policies or laws where a historiological contextual analysis might provide guidance to current efforts. The more policies that are evaluated and monitored for their longer-term impact the more we will learn about approaches that work. Historical archives can be tools for both teaching and decision making.

The complexity of public health systems requires more diverse actions beyond presenting the evidence, including engaging relevant actors, working through best practices for knowledge transfer, building in facilitators and addressing barriers to uptake and implementation of evidence. $^{2}$

A more applied real-world approach to research should also result in stronger research questions, which in turn would make results more applicable and useful. Too often we come across research papers that end with the recommendation for more research. Too rarely do we read papers that prescribe clear guidance for action. Strong research questions embedded in the real-world problems are what's needed, and the way to get this type of paper is to train, from the beginning, strong scientists who are closely engaged with the communities they study. This needs to start with the graduate IVP programmes laying the foundation of our future leaders.

Contributors JMM and LF both contributed to the ideas presented.

Funding The authors have not declared a specific grant for this research from any funding agency in the public, commercial or not-for-profit sectors.

Competing interests None declared.

Patient and public involvement Patients and/or the public were not involved in the design, or conduct, or reporting, or dissemination plans of this research.

Patient consent for publication Not applicable.

Provenance and peer review Commissioned; internally peer reviewed.

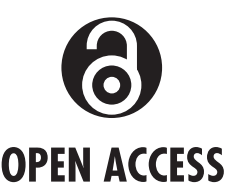

Open access This is an open access article distributed in accordance with the Creative Commons Attribution Non Commercial (CC BY-NC 4.0) license, which permits others to distribute, remix, adapt, build upon this work non-commercially, and license their derivative works on different terms, provided the original work is properly cited, appropriate credit is given, any changes made indicated, and the use is non-commercial. See: http:// creativecommons.org/licenses/by-nc/4.0/.

(C) Author(s) (or their employer(s)) 2021. Re-use permitted under CC BY-NC. No commercial re-use. See rights and permissions. Published by BMJ.

(D) Check for updates

To cite MacKay JM, Fisher L. Inj Prev 2021;27:507.

Published Online First 9 November 2021

Inj Prev 2021;27:507.

doi:10.1136/injuryprev-2021-044471

ORCID iDs

J Morag MacKay http://orcid.org/0000-0001-74677039

Les Fisher http://orcid.org/0000-0002-2746-3924

\section{REFERENCES}

1 Centers for Disease Control and Prevention. The SocialEcological model: a framework for prevention, 2015. Available: https://wwwcdcgov/violenceprevention/ overview/social-ecologicalmodelhtml [Accessed 26 Oct 2021].

2 Vincenten J, MacKay JM, Schröder-Bäck P, et al. Factors influencing implementation of evidence-based interventions in public health systems - a model. Cent Eur J Public Health 2019;27:198-203. 